\title{
MEDIA GAMBAR BERCERITA UNTUK MENINGKATKAN KEMAMPUAN BERBICARA ANAK USIA DINI
}

\author{
Desyanti Kemalasari $\mathrm{N}^{1}$ \\ Ening Widaningsih ${ }^{2}$ \\ Winti Ananthia ${ }^{3}$
}

\begin{abstract}
ABSTRAK
Penelitian ini dilatarbelakangi oleh kurang meningkatnya kemampuan berbicara anak khususnya dalam mengemukakan pendapat, bercerita ataupun merespon guru. Hal tersebut dikarenakan kurang stimulus dari guru, media kurang bervariatif dan lingkungan kurang kondusif. Penelitian ini dilaksanakan di TK Al-Danazar Kecamatan Tanjungsari Kabupaten Sumedang khususnya pada Kelas A dengan jumlah partisipan sebanyak 14 orang yang terdiri dari 6 orang anak laki-laki dan 8 orang anak perempuan. Permasalahan yang ada di kelas A ini diselesaikan dengan menggunakan media gambar bercerita. Tujuan penelitian ini adalah (1) mendeskripsikan penggunaan media gambar bercerita, (2) menggambarkan aktivitas peningkatan kemampuan berbicara anak melalui media gambar bercerita serta (3) memaparkan hasil peningkatan kemampuan berbicara anak setelah menggunakan pembelajaran dengan media gambar bercerita. Peneliti menggunakan metode penelitian tindakan kelas dengan desain penelitian model Elliot. Peneliti mengumpulkan data menggunakan penilaian performa, observasi, wawancara, catatan lapangan serta dokumentasi. Dalam penilaian performa, peneliti menggunakan indikator ketercapaian untuk melihat dan mengukur ketercapaian perkembangan kemampuan berbicara anak. Berdasarkan data yang diperoleh, ada dua cara penggunaan media gambar bercerita yakni dibuat oleh peneliti dan dibuat oleh anak serta diceritakan sendiri oleh ank. Selanjutnya aktivitas anak mengalami peningkatan. Pada siklus III, anak yang mau merespon sebanyak 75,67\%, antusiasme anak sebanyak $91,89 \%$, tidak bermain saat pembelajaran sebanyak $78,37 \%$, mau berpendapat sebanyak $64,84 \%$ dan mau mengikuti seluruh kegiatan sebanyak $100 \%$. Lalu rata-rata kemampuan berbicara anak sebagai berikut: siklus I rata-rata kemampuan berbicara anak sebesar 10,43\%, siklus II menjadi sebesar 35,26\% dan siklus III menjadi 44,55\%. Dari hasil persentase tersebut, media gambar bercerita dapat meningkatkan kemampuan berbicara anak. Adapun rekomendasi yang peneliti ajukan yaitu penggunaan media gambar bercerita untuk meningkatkan kemampuan berbicara anak akan lebih optimal jika didukung oleh metode yang lebih bervariatif dan lebih menarik serta melibatkan anak dalam setiap kegiatannya.
\end{abstract}

Kata kunci: Kemampuan Berbicara, Media Gambar Bercerita

\footnotetext{
1 desyanti.kn@gmail.com

2 Dosen UPI Kampus Cibiru

${ }^{3}$ Dosen UPI Kampus Cibiru
} 


\section{A. PENDAHULUAN}

Masa usia dini merupakan masa- masa yang paling tepat dalam memberikan beragam stimulus guna mengoptimalkan segala aspek perkembangannya. Hal tersebut dikarenakan pada masa usia dini merupakan masa-masa golden age dimana seluruh aspek perkembangannya dapat dikembangkan secara optimal. Pernyataan tersebut sejalan dengan ungkapan yang dikemukakan oleh oleh Yus (2011, hlm.5) yaitu "Masa emas (golden age) perkembangan ialah masa usia dini (masa lahir sampai delapan tahun) sebagai saat kritis dalam rentang perkembangan". Salah satu aspek perkembangan yang dapat dioptimalkan pada masa usia dini yakni perkembangan bahasa anak seperti kemampuan berbicara. Anak-anak pada masa usia dini harus diberikan beragam stimulus supaya anak dapat mempelajari bahasa dan mengembangkan kemampuan berbicaranya dengan baik. Sebaliknya, apabila anak kurang mendapatkan stimulasi berbahasa pada masa usia dini, anak akan mengalami kesulitan dalam mempelajarinya.

Bahasa mempunyai kontribusi yang sangat penting dalam kehidupan setiap individu. Hampir dalam setiap kegiatan dalam kehidupan individu tidak bisa terlepas dari aspek berbahasa dan berbicara termasuk anak-anak dengan pengungkapan bahasa melalui berbicara, anak-anak dapat mengungkapkan pikiran, perasaan serta ekspresinya. Dengan bahasa pula anak-anak dapat bersosialsisasi dengan orang-orang disekitarnya. Lebih dari itu, bahasa merupakan ciri khas atau identitas masyarakat yang menggunakannya.

Secara bertahap kemampuan bahasa yang akan diperoleh oleh anak adalah kemampuan menyimak, berbicara, membaca dan menulis. Keempat kemampuan tersebut memiliki keterkaitan antara satu dengan lainnya. Kamampuan bahasa pertama yakni kemampuan menyimak, kemampuan ini dipelajari anak pertama kali sesuai dengan bahasa ibunya. Ketika anak sudah mampu menyimak maka anak akan mulai mengungkapkannya melalui katakata dan masuk dalam tahap kemampuan berbicara. Setelah anak mampu menguasai kemampuan berbicara maka anak pun akan naik ke tahapan selanjutnya yakni kemampuan untuk membaca. Setelah itu tahap kemampuan berbahasa anak yang terakhir yakni kemampuan anak dalam mengolah katakata melalui tulisan.

Berkaitan dengan aspek berbahasa, kemampuan berbicara anak merupakan hal paling penting dalam kehidupan anak. Anak akan bersosialisasi dengan baik jika kemampuan berbicaranya pun baik. Anak- anak usia Taman Kanak-kanak khususnya sudah harus mampu membuat kalimat yang lengkap. Hal tersebut sejalan dengan pernyataan yang dikemukakan oleh Susanto (2012, hlm.76) "anak usia prasekolah (3-5 tahun) sudah mampu membuat kalimat lengkap." Selain membuat kalimat lengkap, anak-anak usia Taman Kanak-kanak sudah memiliki kemampuan untuk mengungkapkan pendapat ataupun menceritakan dan mendeskripsikan sebuah gambar. Jika anak Taman Kanak-kanak sudah mampu menguasai kemampuan berbicara tersebut maka dapat dikatakan bahwa perkembangan bahasanya telah berjalan dengan baik.

Berdasarkan hasil pengalaman mengajar dan pengamatan yang telah dilakukan oleh peneliti di TK Al-Danazar, kelompok kelas A usia 4-5 tahun 
masih kurang mampu dalam aspek berbahasa khususnya kemampuan berbicara anak.

Diantara 14 anak yakni 8 perempuan dan 6 laki-laki hanya 1 orang anak yang dapat berbicara dengan baik dalam artian sudah mampu mengungkapkan pendapatnya dan sudah mampu mendeskripsikan sesuatu. Pada dasarnya perkembangan bahasa khususnya aspek berbicara anak sudah mulai berkembang namun dalam penyampaiannya masih kurang jelas. Hampir seluruh anak sulit untuk berbicara seperti sulit untuk mengungkapkan keinginannya, pendapatnya dan masih memiliki sikap malu-malu dalam mengungkapkan sesuatu atau mendeskripsikan sesuatu. Hal tersebut terbukti pada saat anak diajak untuk berbicara anak cenderung merasa malu dan kurang jelas apa yang mereka bicarakan. Dari hasil analisis, ada beberapa faktor yang menyebabkan anak kesulitan dalam berbicara seperti kurangnya stimulasi dari guru karena anak hanya diajak untuk duduk diam mengerjakan majalah anak saja, media kurang efektif dan mendukung serta kondisi lingkungan yang kurang kondusif.

Dari hasil analisis tersebut, kondisi seperti itu tidak boleh dibiarkan begitu saja. Guru perlu merencanakan dan melakukan upaya perbaikan agar dapat memfasilitasi kebutuhan anak, khususnya dalam meningkatkan kemampuan berbicara anak supaya anak mampu berpendapat dan mampu mengungkapkan keinginannya dengan baik.

Beragam media dapat dijadikan sebagai sarana penunjang dalam meningkatkan kemampuan berbicara anak. Salah satu media pembelajaran yang dapat digunakan dalam meningkatkan kemampuan berbicara anak yakni media gambar bercerita. Media yang merangsang anak untuk mau berpendapat dan mengungkapkan keinginan anak.

Oleh karena itu, peneliti memfasilitasi kemampuan berbicara anak melalui media gambar bercerita. Pada praktiknya, media gambar bercerita ini terdiri dari dua cara penggunaan, pertama guru yang membuat media gambar bercerita dan guru pula yang menceritakan isi gambar dan penggunaan yang kedua yakni anak sendiri yang membuat dan menceritakan media gambar berceritanya masing-masing.

Berdasarkan hal tersebut, maka rumusan masalah pada penelitian ini yaitu:

1. Bagaimana penggunaan media gambar bercerita pada anak Taman Kanakkanak usia 4-5 tahun (kelompok A)?

2. Bagaimana aktivitas anak Taman Kanak-kanak usia 4-5 tahun (kelompok A) selama penggunaan media gambar bercerita?

3. Bagaimana kemampuan berbicara anak Taman Kanak-kanak usia 4-5 tahun (kelompok A) setelah mengikuti pembelajaran dengan menggunakan media gambar bercerita?

Berdasarkan rumusan masalah, adapun tujuannya yaitu:

1. Mendeskripsikan bagaimana penggunaan media gambar bercerita pada anak Taman Kanak-kanak usia 4-5 tahun (kelompok A);

2. Menggambarkan aktivitas anak Taman Kanak-kanak usia 4-5 tahun (kelompok A) selama penggunaan media gambar bercerita; 
3. Memaparkan bagaimana kemampuan berbicara anak Taman Kanak-kanak usia 4-5 tahun (kelompok A) setelah mengikuti pembelajaran dengan menggunakan media gambar bercerita.

Perkembangan bahasa anak akan berkembang melalui beberapa tahapan yang diawali dengan tahap peniruan bunyi sesuai dengan ungkapan Syaodih (dalam Susanto, 2012, hlm. 73) "Aspek bahasa berkembang dimulai dengan peniruan bunyi dan meraban". Jadi awal mula anak bisa berbahasa dimulai dengan anak menirukan bunyi-bunyi yang diperdengarkan oleh lingkungannya. Setiap bunyi-bunyi yang didengar anak akan anak rekam didalam memorinya sehingga alangkah baiknya ketika anak masih dalam tahap kritis atau golden age, setiap individu yang berada didekat anak harus berhati-hati dalam memperdengarkan sesuatu kepada anak. bila anak diperdengarkan sesuatu yang buruk maka akan terekan dimemori anak dan akan anak ungkapkan ketika ia sudah mulai dapat berbicara. Namun secara umum tahap perkembangan berbahasa anak dapat dibagi kedalam beberapa rentang usia yang masing-masing menunjukkan ciri-ciri tersendiri. Guntur (dalam Susanto, 2012, hlm. 75) mengemukakan tahapan perkembangan bahasa yakni sebagai berikut :

1) Tahap I (pralingusitik) yaitu antara $0-1$ tahun. Terdiri dari tahap :

a) Tahap meraban-1 (pralinguistik pertama).

b) Tahap meraban-2 (pralinguistik kedua).

2) Tahap II (linguistik). Tahap ini terdiri dari :

a) Tahap-1 (holafrastik).

b) Tahap-2 (frasa)

3) Tahap III (pengembangan tata bahasa yaitu prasekolah 3,4,5 tahun).

4) Tahap IV (tata bahasa menjelang dewasa yaitu 6-8 tahun).

Tahap meraban-1 (pralinguistik pertama) ini dimulai dari bulan pertama hingga bulan keenam. Untuk mengekspresikan sesuatu yang mereka rasakan biasanya anak pada tahap ini akan mengungkapkannya melalui menangis, tetawa dan menjerit. Sementara itu tahap meraban- 2 (pralinguistik kedua) pada dasarnya merupakan tahap kata tanpa makna mulai dari bulan ke-6 hingga 1 tahun. Maksudnya anak mengekspresikan sesuatu tanpa makna misalnya anak mulai mengoceh tanpa ada makna berarti dari ocehannya tersebut. Selanjutnya Tahap-1 (holafrastik), tahap ini terjadi pada usia 1 tahun ketika anak-anak mulai menyatakan makna keseluruhan frasa atau kalimat dalam satu kata. Tahap ini juga ditandai dengan pembendaharaan kata anak hingga kurang lebih 50 kosa kata. Maksudnya anak sudah mulai mengenal kata-kata sederhana yakni berupa ucapan satu kata. Setelah tahap holafrastik, anak akan mengalami tahap frasa. Pada tahap ini anak sudah mampu mengucapkan dua kata (ucapan dua kata). Tahap ini juga ditandai dengan pembendaharaan kata anak sampai dengan rentang 50-100 kosa kata. Jadi jika tahap holafrastik anak hanya mampu mengucapkan satu kata dan pembendaharaannya juga hanya 50 kosa kata, pada tahp ini anak sudah mulai memiliki lebih banyak pembendaharaan kata dan pengucapannya pun sudah dapat mengucapkan dua kata. Beranjak pada tahap selanjutnya yakni tahap III, Pada tahap ini anak sudah mampu membuat kalimat seperti telegram. Dilihat 
dari aspek pengembangan tata bahasa seperti: S-P-O, anak dapat memperpanjang kata menjadi satu kalimat. Jadi pada tahap ini anak sudah mampu membuat sebuah kalimat yang cukup lengkap. Tahap terakhir yakni tahap IV, Pada tahap ini ditandai dengan kemampuan yang mampu menggabungkan kalimat sederhana dan kalimat kompleks.

Pada dasarnya tahapan perkembangan bahasa untuk usia Taman Kanakkanak yakni sudah mulai mampu mengungkapkan pendapat yang disesuaikan dengan tata bahasa. Kemampuan berbahasa tersebut dituangkan dalam kemampuan berbicara anak. Tarigan (2013, hlm. 3) mengungkapkan bahwa "Berbicara adalah suatu keterampilan berbahasa yang berkembang pada kehidupan anak, yang hanya didahului oleh keterampilan menyimak dan pada masa tersebutlah kemampuan berbicara atau berujar dipelajari" Jadi kemampuan berbicara anak itu akan berkembang ketika anak sudah mampu menyimak dengan baik, saat anak sudah mampu menyimak maka anak akan belajar secara alami bagaimana dia berbicara. Biasanya anak yang mampu menyimak dengan baik akan mampu berbicara dengan baik pula. Sementara itu Menurut Hurlock (1988, hlm. 176) "Bicara adalah bentuk bahasa yang menggunakan artikulasi atau kata- kata yang digunakan untuk menyampaikan maksud". Maksudnya berbicara itu merupakan salah satu bentuk berbahasa yang diungkapkan melalui pengungkapan bunyi yang berupa kata-kata untuk mengungkapkan pikiran ataupun suatu tujuan tertentu. Jadi salah satu kemampuan berbicara yang harus dimiliki anak usia Taman Kanak-Kanak yakni mengungkapkan pendapat untuk tujuan tertentu. Selain itu menurut Depdiknas Direktorat Jenderal Manajemen Pendidikan Dasar dan Menengah Direktorat Pembinaan Taman Kanak-Kanak dan Sekolah Dasar (2007), kemampuan berbahasa anak usia 45 tahun, anak sudah mampu berbicara dan berkomunikasi secara lisan serta mampu menceritakan sebuah gambar.Sejalan dengan beberapa pendapat tersebut, kemampuan berbicara anak yang ingin ditingkatkan oleh peneliti yakni kemampuan anak untuk mendengarkan dan menceritakan kembali isi cerita yang telah diperdengarkan secara sederhana, menceritakan gambar yang dibuatnya sendiri serta mengurutkan dan menceritakan gambar berseri.

Media yang dipergunakan untuk meningkatkan kemampuan berbicara anak yakni media gambar bercerita. Menurut Davindo (dalam Sarwono 2012, hlm.1) mengatakan bahwa :

gambar adalah sebuah permainan, selama itu tidak memaksa, justru seharusnya dapat menghibur si pembuatnya. Selain itu gambar mengungkapkan banyak kenyataan dalam kehidupan. Gambar adalah sebuah mimpi diatas ketras, dimana muncul keinginan-keinginan baik disadari maupun tidak. Gambar adalah sebuah kenyataan dari pikiranpikiran anak, pada momen tertentu mendorongnya untuk menggambar. Sementara itu Menurut

Moeslichatoen (2004, hlm. 157) mengungkapkan bahwa "bercerita merupakan salah satu pemberian pengalaman belajar bagi anak TK dengan membawakan cerita kepada anak secara lisan." Jadi media gambar bercerita itu merupakan gabungan dari kata gambar dan bercerita yang menjadi sebuah 
media yang dapat digunakan dalam sebuah pembelajaran untuk merangsang anak dan memberikan pengalaman belajar khususnya pengalaman berbicara bagi anak sesuai dengan keinginan mereka.

\section{B. METODE}

Penelitian ini dilaksanakan di TK Al- Danazar, yang beralamat di Jalan Cijambu No. 56 Kecamatan Tanjungsari Kabupaten Sumedang. Partisipan adalah anak kelompok A tahun ajaran 2014-2015 yang berjumlah 14 orang anak, terdiri dari 8 orang anak perempuan dan 6 orang anak laki-laki.

Desain penelitian yang digunakan adalah desain penelitian tindakan kelas yang dikembangkan oleh Elliot. Desain penelitian ini, tidak seperti desain penelitian model lain yang menyarankan bahwa satu siklus hanya terdiri atas satu tindakan. Dalam desain penelitian model Elliot, dalam pelaksanannya satu siklus terdiri atas beberapa tindakan. Desain penelitian ini dipilih karena sesuai dengan permasalahan yang akan dipecahkan peneliti, yakni mengenai kemampuan kosakata yang membutuhkan pengulangan dalam memahaminya.

Instrumen penelitian yang digunakan pada saat penelitian yang meliputi: penilaian performa, lembar pedoman observasi terhadap aktivitas guru, lembar pedoman observasi terhadap aktivitas anak, catatan lapangan, lembar pedoman wawancara dan kamera foto untuk mendokumentasikan kegiatan pembelajaran. Teknik pengumpulan data dilakukan dengan teknik observasi, wawancara dan dokumentasi. Adapun dalam instrumen penelitian pedoman penilaian performa yang dinilai yakni kemampuan anak untuk mendengarkan dan menceritakan kembali isi cerita secara sederhana, menceritakan gambar yang disediakan atau yang dibuatnya sendiri serta mengurutkan dan menceritakan gambar berseri. Sementara itu pedoman observasi aktivitas yang dinilai terhadap anak yakni kemampuan anak untuk menyimak dan merespon guru, mengikuti kegiatan dengan antusias, tidak main-main saat pembelajaran berlangsung, mengikuti seluruh kegiatan serta mau mengemukakan pendapat.

Analisis data kualitatif bersumber dari lembar observasi, lembar wawancara, dan dokumentasi. Sedangkan, analisis data kuantitatif di dapat dari performa aktivitas anak dan hasil kemampuan berbicara anak selama mengikuti proses pembelajaran dan penelitian. Data yang telah diperoleh diklasifikasikan, dianalisis, kemudian disimpulkan. Data yang bersifat kualitatif, dideskripsikan. Dalam menganalisis data kuantitatif, peneliti menggunakan statistik deskriptif untuk menentukan rata-rata. Rumus yang digunakan yaitu:

Rata-rata $=\underline{\text { Jumlah skor yang diperoleh oleh anak }}$

$$
\text { Jumlah anak }
$$

Kemudian, hasil rata-rata yang telah didapatkan tersebut dipersentasekan. Selanjutnya, untuk menguji keabsahan data dilakukan dengan trianggulasi. Triangulasi merupakan teknik pengumpulan data yang menggabungkan beberapa teknik data yang bersumber dari data kualitatif dan data kuantitatif. Data yang didapat kemudian dibandingkan satu sama lain yang saling berkaitan. Proses membandingkan tersebut adalah untuk mengecek derajat kebenaran dari masing-masing sumber data. 


\section{PEMBAHASAN}

Penelitian yang dilakukan terdiri dari tiga siklus, dalam setiap siklus terdapat tiga tindakan. Setiap tindakan memiliki indikator ketercapaian yang berbeda-beda namun memiliki pola yang sama pada setiap siklusnya. Dalam setiap siklus dan tindakan menggunakan media gambar bercerita yang berbeda-beda. Pada tindakan 1 setiap siklusnya, media gambar bercerita khusus disediakan oleh guru dan guru pula yang bercerita. Sementara iti pada tindakan 2 setiap siklusnya, anak diajak untuk membuat gambar bercerita sendiri dengan bahan pencil and paper. Pada tindakan 3 setiap siklusnya anak membuat gambar bercerita sendiri dengan bahan yang lebih menarik lagi. Pada setiap hasil tindakan yang telah dilaksanakan, semuanya dideskripsikan pelaksanaan kegiatannya dari kegiatan awal hingga akhir, dianalisis kemudian direfleksi pada setiap siklusnya untuk mengetahui kelebihan dan kekurangan dari setiap siklus yang telah dilaksanakan. Rincian dari setiap siklus tersebut adalah sebagai berikut:

\section{Siklus 1}

Pelaksanaan siklus 1 terdiri dari tiga tindakan. Tema yang digunakan adalah pedesaan dan perkotaan dengan sub tema mata pencaharian yang ada dipedesaan. Kemampuan berbicara yang ingin ditingkatkan pada tindakan 1 ini yakni kemampuan anak untuk mendengarkan dan menceritakan kembali isi cerita secara sederhana. Media gambar bercerita yang dipergunakan berupa media flash card yang berisi gambar Bapak Tani, Bapak Nelayan dan Ibu Jamu. Sementara itu pada tindakan 2, kemampuan berbicara anak yang ingin ditingkatkan adalah kemampuan anak untuk menceritakan gambar yang telah dibuatnya. Media gambar bercerita pada tindakan 2 yakni gambar anak sendiri. Selanjutnya pada tindakan 3 kemampuan berbicara yang ingin ditingkatkan yakni kemampuan anak untuk mengurutkan dan menceritakan gambar berseri dengan media gambar bercerita berupa majalah mini yang dibuat sendiri oleh anak.

Kegiatan awal diisi dengan bernyanyi, berdo'a, permainan hingga bercakap-cakap dan pengulangan kegiatan sebelumnya terlebih dahulu. Kegiatan inti diisi dengan proses pembelajaran dengan menggunakan media gambar bercerita yang telah dipaparkan sebelumnya. Kegiatan istirahat diisi dengan makan bersama dan bermain. Kegiatan penutup diisi dengan melakukan tanya jawab atau bercakap- cakap dengan anak mengenai kegiatan yang telah dilakukan pada hari itu. Berdasarkan kegiatan pembelajaran peningkatan kemampuan berbicara anak melalui media gambar bercerita yang telah dilakukan, temuan yang ditemukan pada siklus I sebagai berikut.

1. Anak belum mampu merespon guru dengan baik ketika guru bercerita

2. Anak masih belum mampu memperhatikan teman-temannya saat bercerita

3. Masih banyak anak yang belum berani untuk mengungkapkan pendapatnya

4. Anak masih main-main dalam melaksanakan kegiatan

5. Media gambar bercerita yang disajikan kurang menarik dan kurang besar ukurannya untuk anak sehingga anak tidak fokus terhadap guru

Berdasarkan temuan-temuan yang telah ditemukan peneiti pada siklus I, peneliti memperbaiki kekurangan- kekurangan yang terjadi. Peneliti harus 
memberikan media gambar bercerita yang lebih menarik dan dapat dilihat oleh seluruh anak sehingga anak-anak mampu fokus terhadap guru. Selain itu peneliti pun harus mampu membuat peraturan untuk membuat kelas lebih kondusif lagi. Sementara itu aktivitas anak pada siklus I ini yakni kemampuan anak untuk menyimak dan merespon guru sebesar $48,48 \%$, antusiasme anak dalam mengikuti kegiatan sebanyak $54,54 \%$, anak yang tidak bermain-main saat kegiatan berlangsung sebanyak 57,57\%, anak yang mengikuti seluruh kegiatan sebanyak 96,96\% dan anak yang mau mengemukakan pendapatnya sebanyak $21,21 \%$.

\section{Siklus II}

Tema yang digunakan pada siklus II masih sama yakni pedesaan dan perkotaan. Namun subtema yang diberikan pada tiap tindakan berbeda. Tindakan 1 subtemanya yakni hal yang sering terjadi diperkotaan. Kemampuan berbicara yang ingin ditingkatkan yakni kemampuan anak mendengar dan menceritakan kembali isi cerita. Media gambar bercerita yang mendukungnya yakni mini book dengan judul "Rumahku Kebanjiran". Sementara itu pada tindakan 2 subtema yang disajikan yakni keadaan diperkotaan dengan kemampuan berbicara yang ingin dicapai adalah menceritakan gambar yang dibuat sendiri dengan media gambar bercerita berupa karya anak. Pada tindakan 3 subtemanya adalah gabungan dari tindakan 1 dan 2 dengan kemampuan berbicara yang ingin dicapai yaitu mengurutkan dan menceritakan gambar berseri. Media gambar bercerita yang disajikan pada kegiatan ini yakni pop up book sederhana yang dibuat sendiri oleh anak.

Kegiatan awal diisi dengan bernyanyi, berdo'a, permainan hingga bercakap-cakap dan pengulangan kegiatan sebelumnya terlebih dahulu. Kegiatan inti diisi dengan proses pembelajaran dengan menggunakan media gambar bercerita yang telah dipaparkan sebelumnya. Kegiatan istirahat diisi dengan makan bersama dan bermain. Kegiatan penutup diisi dengan melakukan tanya jawab atau bercakap- cakap dengan anak mengenai kegiatan yang telah dilakukan pada hari itu. Kegiatan penutup diisi dengan melakukan tanya jawab atau bercakap-cakap dengan anak mengenai kegiatan bermain yang telah dilakukan. Berdasarkan kegiatan yang telah dilakukan, temuan yang ditemukan pada siklus II masih ada anak yang bermain-main saat pembelajaran, namun antusiasme anak sudah cukup meningkat karena media yang digunakan lebih besar dan lebih menarik meskipun ada media yang sulit untuk dibuat oleh anak. Perbaikan untuk siklus selanjutnya yakni guru harus mampu mempertahankan media yang menarik dan harus lebih banyak memberikan reward serta motivasi supaya anak tidak main- main lagi saat pembelajaran.

Sementara itu aktivitas anak pada siklus II ini yakni kemampuan anak untuk menyimak dan merespon guru sebesar $60,60 \%$, antusiasme anak dalam mengikuti kegiatan sebanyak 75,75\%, anak yang tidak bermain-main saat kegiatan berlangsung sebanyak 69,69\%, anak yang mengikuti seluruh kegiatan sebanyak $100 \%$ dan anak yang mau mengemukakan pendapatnya sebanyak $48,48 \%$. 


\section{Siklus III}

Tema yang digunakan pada siklus III adalah berbeda-beda. Pada tindakan 1 temanya adalah tanaman dengan subtema sayuran. Kemampuan berbicara yang ditingkatkan pada tindakan 1 yaitu kemampuan mendengarkan dan menceritakan kembali isi cerita dengan media gambar bercerita yang diperlihatkan pada anak berupa mini book flanel yang dilengkapi dengan wayang. Judul cerita yang dibawakan yakni "Petualangan Cici Kelinci". Sementara itu pada tindakan 2 tema yang disajikan yakni diri sendiri dengan subtema kesukaanku. Sama dengan tindakan 2 pada siklus-siklus sebelumnya, kemampuan berbicara yang ingin ditingkatkan pada tindakan 2 ini adalah menceritakan gambar yang dibuat oleh anak dengan media gambar bercerita berupa karya anak sendiri. Selanjutnya pada tindakan 3 tema yang diangkat sama dengan tindakan 2 dengan kemampuan berbicara yang ingin dicapai yakni anak mampu mengurutkan dan menceritakan gambar seri sederhana. Media gambar bercerita yang dibuat sendiri oleh anak pada tindakan 3 ini berupa gambar berseri dari majalah bekas.

Kegiatan awal diisi dengan bernyanyi, berdo'a, permainan hingga bercakap-cakap dan pengulangan kegiatan sebelumnya terlebih dahulu. Kegiatan inti diisi dengan proses pembelajaran dengan menggunakan media gambar bercerita yang telah dipaparkan sebelumnya. Kegiatan istirahat diisi dengan makan bersama dan bermain. Kegiatan penutup diisi dengan melakukan tanya jawab atau bercakap- cakap dengan anak mengenai kegiatan yang telah dilakukan pada hari itu. Kegiatan penutup diisi dengan melakukan tanya jawab atau bercakap-cakap dengan anak mengenai kegiatan bermain yang telah dilakukan. Berdasarkan kegiatan yang telah dilakukan dalam proses pembelajaran peningkatan kemampuan berbicara anak melalui media gambar bercerita, temuan yang ditemukan pada siklus III sebagai berikut.

1. Anak-anak yang bermain saat pembelajaran sudah berkurang

2. Anak-anak sudah mampu dikondisikan

3. Anak-anak sudah mau memperhatikan teman-temannya ketika bercerita

4. Media gambar bercerita yang disajikan dan dibuat oleh anak lebih menarik dan lebih mudah untuk dibuat oleh anak

Berdasarkan temuan-temuan pada siklus III, dapat disimpulkan bahwa anak- anak telah mampu mengikuti urutan kegiatan dengan baik, anak sudah mampu memperhatikan teman-temannya dan media gambar bercerita yang dibuat dan disajikan pada anak pun lebih mampu menarik minat anak sehingga anak lebih mau berpendapat dan kemampuan berbicara anak pun mengalami peningkatan.

Sementara itu aktivitas anak pada siklus III pun mengalami peningkatan yakni kemampuan anak untuk menyimak dan merespon guru sebesar 75,67\%, antusiasme anak dalam mengikuti kegiatan sebanyak 91,89\%, anak yang tidak bermain-main saat kegiatan berlangsung sebanyak $78,37 \%$, anak yang mengikuti seluruh kegiatan sebanyak $100 \%$ dan anak yang mau mengemukakan pendapatnya sebanyak $64,84 \%$.

Secara keseluruhan, penilaian performa dan juga aktivitas anak serta 
hasil kemampuan berbicara anak mengalami peningkatan dari siklus ke siklus. Temuan berupa kekurangan-kekurangan pada proses pelaksanaan pembelajaran di setiap siklus, diperbaiki pada siklus berikutnya agar tujuan pembelajaran dapat tercapai secara maksimal dan optimal. Jika pada siklus I guru belum mampu mendapatkan respon dengan baik serta media gambar bercerita yang dipergunakan kurang menarik bagi anak, guru memperbaiki keadaan tersebut pada siklus II dan III agar peningkatan kemampuan berbicara anak dapat tercapai.

Media pembelajaran yang diberikan kepada anak adalah salah satu faktor penting dalam proses pembelajaran. Semakin menarik media yang digunakan, semakin anak bergairah dalam belajar. Hal tersebut sejalan dengan yang dikemukakan oleh John Dewey (dalam Yus, 2010, hlm.6) bahwa "Minat anak menjadi hal yang penting dalam pembelajaran."

Penggunaan media gambar bercerita dalam proses peningkatan kemampuan berbicara anak di TK Al-Danazar mampu meningkatkan performa dan aktivitas anak pada saat pembelajaran berlangsung. Selain itu, media gambar bercerita yang dihadirkan oleh guru dapat memberikan stimulasi pada anak sehingga anak lebih aktif dalam mengikuti pembelajaran.

Faktor lain yang ikut berperan dalam menentukan agar dapat mencapai tujuan pembelajaran yang diharapkan adalah pengkondisian anak. Guru harus mampu membuat suasana kelas menjadi lebih kondusif, agar materi yang disampaikan kepada anak mampu terserap dengan optimal oleh anak. Media gambar bercerita yang telah disajikan mampu meningkatkan kemampuan anak dari siklus ke siklus. Berikut ini merupakan peningkatan rata- rata kemampuan berbicara anak pada setiap siklusnya dilihap dari peningkatan perolehan bintang 3 .

Gambar 1. Persentase rata-rata kemampuan berbicara anak RATA-RATA KEMAMPUAN BERBICARA ANAK KELOMPOK A

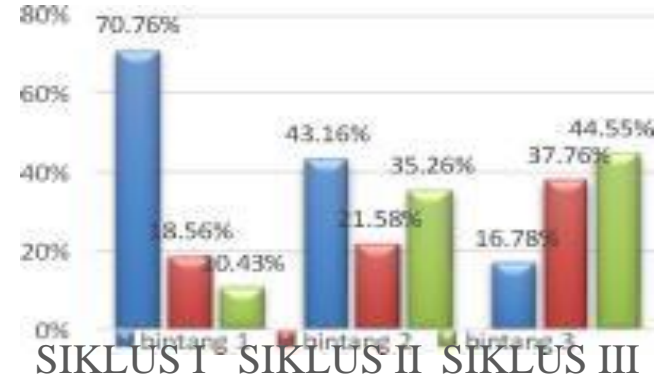

Berdasarkan gambar diatas dapat diketahui bahwa rata-rata kemampuan berbicara anak melalui media gambar bercerita mengalami peningkatan dari siklus I ke siklus III. Pada siklus I, perolehan bintang 1 masih tinggi sebanyak 70,76\% lalu menurun pada siklus II menjadi $43,16 \%$ dan semakin menurun pada siklus 3 menjadi $19,34 \%$ yang artinya anak yang belum mampu berbicara dengan bercerita baik itu menceritakan kembali isi cerita yang diperdengarkan peneliti, menceritakan gambar sendiri maupun menceritakan gambar berseri telah berkurang.

Kemudian bintang 2 yang didapat anak meningkat dari siklus I sampai 
siklus III. Pada siklus I perolehan bintang 2 masih rendah yakni sebanyak 18,56\% lalu meningkat pada siklus II menjadi sebanyak $21,58 \%$ dan kembali meningkat pada siklus III menjadi $37,76 \%$ yang artinya anak yang mampu berbicara sudah meningkat.

Selanjutnya perolehan bintang sempurna yakni bintang 3 dari siklus I sampai siklus III pun mengalami peningkatan. Pada siklus I perolehan bintang 3 sebanyak 10,43\% lalu meningkat pada siklus II meningkat menjadi 35,26\% dan semakin meningkat menjadi 44,55\% yang artinya kemampuan anak dalam menceritakan kembali isi cerita dengan jelas dan berurutan meningkat. Begitupun dengan kemampuan anak dalam menceritakan gambar yang telah dibuatnya dengan jelas dan tepat sasaran pun meningkat.

Serta kemampuan anak dalam menceritakan 3 hingga 4 gambar berseri dengan jelas dan berurutan pun meningkat. Jadi dapat diambil kesimpulan bahwa rata- rata kemampuan berbicara anak melalui media gambar bercerita mengalami peningkatan. Kemampuan berbicara anak pun semakin mengalami pengingkatan dalam setiap siklusnya. Hal tersebut ditandai dengan tercapainya indikator kemampuan berbicara anak selama proses pelaksanaan kegiatan_pembelajaran peningkatan kemampuan berbicara dengan menggunakan media gambar bercerita berlangsung. Selain rata-rata kemampuan berbicara anak yang terlihat meningkat dari tiap siklusnya disesuaikan dengan perolehan bintang yang diperoleh oleh masing-masing anak, peneliti pun membuat persentase kemampuan berbicara anak dilihat dari bintang sempurna yang didapatkan anak untuk memperjelas bahwa kemampuan berbicara anak melalui media gambar bercerita telah mengalami peningkatan, berikut peneliti menjabarkan presentase peningkatan kemampuan berbicara anak dari siklus I, II dan III melalui gambar berikut ini.

Berdasarkan gambar tersebut dapat dilihat bahwa kemampuan berbicara anak melalui media gambar bercerita telah mengalami peningkatan. Pada siklus I kemampuan berbicara anak dilihat dari perolehan bintang terbesar sebanyak 10,43\%. Lalu mengalami peningkatan pada siklus II menjadi 35,26\% dan kembali meningkat pada siklus III menjadi 44,55\%. Jadi dapat diasumsikan bahwa penelitian ini telah berhasil dengan adanya peningkatan kemampuan berbicara pada anak TK Al-Danazar kelompok A.

Berdasarkan data yang telah diperoleh dari penilaian performa serta aktivitas anak kemampuan berbicara anak melalui media gambar bercerita mengalami peningkatan pada setiap siklusnya. Jadi dapat disimpulkan bahwasanya media gambar bercerita dapat dijadikan salah satu media pembelajaran yang cocok dan tepat untuk digunakan sebagai sarana peningkatan kemampuan berbicara pada anak usia dini khususnya anak kelas TK A.

\section{PENUTUP}

Media gambar bercerita yang ditujukan untuk meningkatkan kemampuan berbicara anak usia dini khususnya anak Taman Kanak-kanak Kelompok A di Taman Kanak-kanak Al-Danazar dilaksanakan dalam tiga siklus yang setiap siklusnya dibagi kedalam tiga tindakan. Berikut simpulan yang didapat oleh peneliti berdasarkan data yang diperoleh:

1. Penggunaan media gambar bercerita dalam setiap siklusnya memiliki pola 
yang sama. Pada tindakan 1 dalam setiap siklus peneliti menggunakan metode bercerita dan menggunakan gambar bercerita yang dibuat sendiri oleh peneliti untuk disajikan pada anak dengan indikator kemampuan berbicara yang ingin dicapai yaitu anak mampu mendengarkan cerita dan menceritakan kembali isi cerita sederhana. Pada tindakan 2 dalam setiap siklusnya peneliti membebaskan anak untuk membuat media gambar berceritanya sendiri dengan bahan pencil and paper dengan indikator kemampuan berbicara yang ingin dicapai yaitu anak mampu bercerita tentang gambar yang disediakan atau yang dibuatnya sendiri. Selanjutnya pada tindakan 3 dalam setiap siklusnya peneliti mengajak anak membuat media gambar bercerita dengan bahan yang ada disekitar anak dan bukan merupakan pencil and paper membentuk gambar berseri dengan indikator kemampuan yang ingin dicapai yaitu anak mampu mengurutkan dan menceritakan isi gambar seri sederhana.

2. Aktivitas anak selama mengikuti pembelajaran menggunakan media gambar bercerita mengalami peningkatan. Kemampuan anak untuk menyimak dan merespon meningkat dari 48,48\% menjadi sebesar 75,67\%, antusiasme meningkat menjadi $91,89 \%$ dari yang asalnya sebesar $54,54 \%$, anak yang tidak bermain-main pun meningkat dari 57,57\% menjadi sebesar 78,37\%, anak yang mau mengikuti keseluruhan kegiatan pun meningkat pula dari $96,96 \%$ menjadi $100 \%$ serta anak yang mau mengemukakan pendapat dari $21,21 \%$ meningkat menjadi $64,84 \%$.

3. Kemampuan berbicara anak kelompok A di Taman Kanak-kanak Al-Danazar menggunakan media gambar bercerita mengalami peningkatan yang cukup baik dari siklus ke siklus. Hal tersebut terlihat dari persentase perolehan bintang 1, 2 dan 3 pada setiap siklusnya. Pada siklus I, anak yang mendapatkan bintang 1 sebanyak 70,76\% sementara bintang 2 sebanyak $18,56 \%$ serta bintang 3 sebanyak 10,43\%. Selanjutnya pada siklus II, kemampuan berbicara anak yang ditandai dengan bertambahnya perolehan bintang 2 dan 3 serta berkurangnya anak yang mendapatkan bintang 1. Pada siklus II, anak yang mendapatkan bintang 1 berkurang menjadi sebanyak 43,16\%, perolehan bintang 2 meningkat menjadi 21,58\% dan perolehan bintang 3 pun mengalami peningkatan pula menjadi sebanyak $35,26 \%$. Sementara itu pada siklus III, kemampuan berbicara anak semakin meningkat lagi. Dari data yang ada, perolehan bintang 1 pada siklus III semakin menurun menjadi 19,34\%, pemerolehan bintang 2 meningkat menjadi 37,76\% dan perolehan bintang 3 pun mengalami peningkatan menjadi sebesar 44,55. Kemampuan berbicaraanak yang mengalami peningkatan dalam penelitian ini yakni kemampuan anak untuk menceritakan kembali isi cerita secara sederhana dengan jelas dan berurutan, lalu kemampuan berbicara anak dalam hal menceritakan gambar yang dibuatnya sendiri dengan jelas dan tepat sasaran artinya sesuai dengan kondisi gambar yang mereka buat serta kemampuan berbicara yang terakhir yakni anak mampu menceritakan gambar berseri sebanyak 1 sampai 3 gambar secara berurutan.

\section{DAFTAR PUSTAKA}

Depdiknas Direktorat Jenderal Manajemen Pendidikan Dasar dan Menengah 
Direktorat Pembinaan Taman Kanak-Kanak dan Sekolah Dasar (2007). Pedoman pembelajaran bidang pengembangan berbahasa di taman kanak-kanak.

Hurlock, E. (1988). Perkembangan Anak. Bandung : Erlangga Moeslichatoen. (2004). Metode pengajaran di taman kanak-kanak. Jakarta : Rineka Cipta Sarwono, S. (2012). Mengenal anak melalui gambar. Jakarta : Salemba Humanika

Susanto, Ahmad. (2012). Perkembangan Anak Usia Dini Pengantar dalam Berbagai Aspeknya. Jakarta : Kencana

Tarigan, H. G. (2013). Berbicara sebagai suatu keterampilan berbahasa.

Bandung: CV Angkasa Yus, Anita. (2011). Model pendidikan anak usia dini. Jakarta : Kencana 